\title{
Role of Elastases in the Pathogenesis of Chronic Obstructive Pulmonary Disease: Implications For Treatment
}

\author{
U. Demkow ${ }^{1}$, F. J. van Overveld ${ }^{2}$ \\ ${ }^{1}$ Department of Laboratory Diagnostics and Clinical Immunology of Developmental Age, Warsaw Medical University, Warsaw, Poland; \\ 2Immunologist, Waterloo, Belgium
}

\begin{abstract}
Neutrophil elastase, metalloproteinases, and their inhibitors play an important role in the development of chronic obstructive pulmonary disease (COPD), resulting in extensive tissue damage and malfunctioning of the airways. Nearly fifty years after the protease-antiprotease imbalance hypothesis has been suggested for the cause of emphysema, it is still appealing, but it does not explain the considerable variation in the clinical expressions of emphysema. However, there are many recent research findings to support the imbalance hypothesis as will be shown in this review. Although limited, there might be openings for the treatment of the disease.
\end{abstract}

Key words: antiproteinases, COPD, metalloproteinases, neutrophil elastase, pathogenesis, treatment

\section{Chronic Obstructive Pulmonary Disease}

Chronic obstructive pulmonary disease (COPD) is one of the major health care problems in the present world. The global prevalence of COPD in adults 40 years or older is approximately $9-10 \%$ and is higher in smokers than in non-smokers, and higher in men than in women (Halbert et al 2006). COPD is an important cause of death in many countries and the incidence is still increasing because of the expanding epidemic of smoking and the increasingly aging population (Chapman et al 2006). Because of its increasing incidence, the World Health Organization (WHO) in collaboration with the US National Institutes of Health formed the Global Initiative for chronic obstructive lung disease (GOLD). The GOLD definition describes COPD as 'A disease state characterized by airflow limitation that is not fully reversible, and that is usually both progressive and associated with an abnormal inflammatory response of the lungs to noxious particles or gases' (Pauwels et al 2001). Classically, COPD involves the three morphological forms chronic bronchitis, emphysema, and small airway disease. However, these pathologic entities can be present in mixed forms in the same patient (Jeffery 2001).Chronic bronchitis is characterized by cough with expectoration due to mucus hypersecretion, which does not always lead to airway obstruction. Goblet cell hyperplasia is observed in the bronchial wall, but the excessive mucus production correlates poorly with the mucus gland mass (Yoshida and Tuder 2007). Emphysema is char- acterized by a permanent air space enlargement due to a process of alveolar destruction and is not associated with significant fibrosis (Snider et al 1985, 1986). Damage to the alveolar wall and attachment destruction leads to the loss of elastic recoil. There are two major types of emphysema, according to the distribution within the acinus: centrolobular and panlobular. The centrolobular form involves dilatation and destruction of the respiratory bronchioles, while the panlobular form of emphysema involves the destruction of the whole of the acinus. The former is the most common type of emphysema in COPD and is more prominent in the upper zones, while the latter predominates in patients with $\alpha_{1}$-antitrypsin deficiency and is more prominent in the lower zones.

\section{COPD AND INFLAMMATION}

All these morphological forms of COPD, chronic bronchitis, small airway disease, and emphysema are accompanied by airway inflammation. The inflammatory cell profile in the alveolar walls and the air spaces is similar to that described in the airways and persists throughout the course of the disease (Finkelstein et al 1995). An increase in neutrophils, macrophages, and T-lymphocytes in various parts of the lung is characteristic and relates to the degree of airflow limitation (Saetta et al 1998). There may be an increase in eosinophils in some patients as well, particularly during exacerbations (Saetta et al 1994, 1996). These inflammatory cells are capable of releasing a variety of cytokines and inflammatory mediators. In addition, the airway epithelium is a rich source of cytokines and chemokines that recruit both neutrophils and macrophages into the airspaces. Many of these cytokines are overexpressed in COPD (Chung 2001; MacNee 2007). The pro-inflammatory cytokines IL-1 $\beta$ and TNF- $\alpha$ are released by airway epithelial cells during inflammatory reactions induced by infection, injury, or smoking cigarettes. Both cytokines share biological functions through some common signal transduction pathways (Stewart and Marsden 1995). The expression of metalloproteinases and other enzymes involved in the degradation of connective tissue proteins is stimulated by IL- $1 \beta$ in close connection with TNF- $\alpha$ (Cao et al 1996; Churg et al 2002, 2003a, 2004; Kusano et al 1998). The neutrophils release a large array of serine proteases including elastase, proteinase-3 and cathepsin $G$, all are able to induce emphysema in 
animal models (Stockley 1983) by destroying the elastin and components of the alveolar wall (Saetta et al 2001). It has been shown that during cardiopulmonary bypass surgery increased levels of plasma elastase and metalloproteinases (MMPs) occur, which may cause pulmonary injury (De Backer et al 1996; Steinberg et al 2001). Neutrophils may also play a role in the mucus hypersecretion, which is characteristic for chronic bronchitis. All neutrophil proteases are potent secretagogues (Nadel 1991; Sommerhoff et al 1990; Witko-Sarsat et al 1999). Elastase is also a very potent inducer of mucus gland hyperplasia (Sommerhoff et al 1990).

\section{PROTEASES AND THEIR INHIBITORS}

Elastase is a serine proteinase with a primary translational product of 267 amino acids and variable glycosylation, migrating with a molecular mass of 28 to 31 kiloDalton $(\mathrm{kDa})$ (Sinha et al 1987). The N-terminal amino acid sequence is strongly homologous with that of pancreatic elastase. Interestingly, the pancreatic elastase is generated from pro-elastase by tryptic cleavage of an $\mathrm{N}$-terminal activation peptide, whereas no pro-enzyme has been detected for the elastase (Barrett 1981). Elastase is synthesized in the promyelocytic stage of myeloid development and stored in large quantities in its active form in neutrophil azurophilic granules (Takahashi et al 1988). Elastase has potent catalytic activity against a broad array of extracellular matrix substances, such as elastin (Senior et al 1976), cartilage proteoglycan (Roughley and Barrett 1977), collagen types I and II (Starkey et al 1977), type III (Gadek et al 1980), type IV (Davies et al 1978), and fibronectin (McDonald and Kelley 1980). Both neutrophils and macrophages are also able to produce metalloproteinases, which are likely to contribute to injury of the lung. Cigarette smoke exposure induces either directly or indirectly the production of MMP-1 (collagenase), MMP-9 (gelatinase B), MMP-12 (macrophage elastase), and other metalloproteinases by macrophages (Shapiro 1999). A deregulated expression of these metalloproteinases could lead to the lung destruction characteristic of emphysema. MMP-12 is a $54 \mathrm{kDa}$ proenzyme that is processed by loss of both $\mathrm{N}$ - and C-terminal residues into a $40 \mathrm{kDa}$ and then to a $22 \mathrm{kDa}$ active form. It has been suggested that MMP-12 gene polymorphisms may account for the activity of MMP-12 in various diseases and that it is one of the causative factors in smoking related lung injury (Belvisi and Bottomley 2003). In healthy humans, the lung is protected by a variety of antiproteases that quickly inactivate free proteases. The major antiproteases which are also involved in the pathogenesis of COPD include $\alpha_{1}$-antitrypsin, $\alpha_{1}$-antichymotrypsin, secretory leukocyte proteinase inhibitor (SLPI), elafin, cystatins and tissue inhibitors of metalloproteinases (TIMP), including TIMP-1, TIMP-2, and TIMP-3. In the lung, alpha-1-antitrypsin (A1AT), also known as serum trypsin inhibitor, is the most predominant antiprotease. A1AT is a single chain glycoprotein consisting of 394 amino acids. A1AT belongs to the family of serine protease inhibitors, known as serpins. A1AT has the ability to inhibit a wide variety of proteases, but it has the highest affinity for elastase. Normal physiological concentrations of A1AT in adults' serum ranges from 1.5-3.5 g/1, but the concentration will rise many folds upon acute inflammation. This up-regulation is required to balance the secretion of elastase by neutrophilic granulocytes. Also during infection, cancer and pregnancy an increase in serum concentration of A1AT occurs. SLPI has a lower association rate constant for elastase than A1AT and is partially reversible, meaning that SLPI is not equipotent to A1AT, although it does inhibit on a one-to-one molar basis. Elafin has a similar affinity to elastase as A1AT, but both SLPI and elafin are present at lower concentrations than A1AT (Gettins 2002; Williams et al 2006).

\section{ALPHA-1-ANTITRYPSIN DEFICIENCY}

Deficiency of A1AT, a rare genetic condition with autosomal co-dominant inheritance (Köhnlein and Welte 2008), was first recognized in 1963 (Laurell and Eriksson 1963) and classically presents with emphysema in young- to middle-aged adults. They described an association between familial emphysema and deficiency of A1AT. Shortly thereafter Fagerholm described the allelic variation of A1AT (Fagerholm and Laurell 1967). Two mutations in the A1AT gene have been associated with decreased A1AT serum levels (Siafakas and Tzortzaki 2002). Other researchers proposed that A1AT deficiency is one of the most common hereditary disorders in the world (de Serres 2002). In total, there are at least 120 million carriers of defective alleles, which are populations at risk for emphysema development and 3.4 million carriers of deficiency allele combinations who may eventually develop COPD. These individuals with A1AT deficiency only account for a small proportion of the total COPD burden. Much more than 70 different variants are recognized and they are classified according to their proteinase inhibitor (Pi) properties (Brantly et al 1998). The most common phenotype presenting with clinical evidence of A1AT deficiency is PiZZ or Znull. The serum concentration of A1AT in patients with genotype PiZ is about $10-15 \%$ of normal concentrations. Acquired deficiency is much more common and occurs because of the inactivation of a methionine residue in the active site of A1AT by free oxygen radicals and substances present in cigarette smoke. A1AT is an acute-phase reactant with anti-protease properties mainly synthesized by liver cells and the Z-variant of A1AT is retained as inclusion bodies in the endoplasmic reticulum of hepatocytes (Sandford and Silverman 2002). Thus A1AT deficiency is merely a failure in the secretion rather than in the biosynthesis of A1AT that leads to the deficiency (Crystal 1989; Luisetti and Seersholm 2004). Vitamin D-binding protein (VDBP, also known as a group-specific component or Gc-globulin) is the main systemic transporter of $1,25(\mathrm{OH})_{2}$ vitamin D3 and is essential for its cellular endocytosis (Ongagna et al 2005). It is a highly expressed polymorphic protein that is a precursor to inflammation-primed macrophage activating factor (GcMAF) (Nagasawa et al 2004) and can significantly enhance leukocyte chemotactic activity to C5a and C5a des-Arg (Zhang and Kew 2004). Thus, it can regulate the inflammatory 
response or diminish antioxidative capacity of the host. A decreased frequency of 2-2 genotype of VDBP was reported in COPD patients (Zhang and Kew 2004), but this was not replicated (Kueppers et al $1977 \mathrm{a}, 1977 \mathrm{~b})$. In the last 10 years, many publications reviewed the genetic profile of COPD (Hoidal 2001; Sampsonas et al 2006; Sandford et al 2002; Sandford and Silverman 2002; Snider 2003). These data indicate that in addition to A1AT deficiency, other forms of genetic susceptibility also play a crucial role in COPD development. Alpha-2-macroglobulin is a protease inhibitor, and its serum deficiency is very rare. There are only case reports of COPD patients and $\alpha_{2}$-macroglobulin polymorphism (Poller et al 1989).

\section{The ImbalanCE Hypothesis}

The 'protease-antiprotease imbalance' hypothesis for the development of emphysema has been postulated more than forty years ago (Eriksson 2008), who demonstrated for the first time the existence of A1AT deficiency (Laurell and Eriksson 1963), and this hypothesis is still supported. The hypothesis is appealing but does not explain the considerable variation in the clinical expression of emphysema in individuals who smoke cigarettes, as is shown in this review. Only 10 $15 \%$ of A1AT-deficient individuals (Burdon et al 1996) and 10-20\% of cigarette smokers develop emphysema (Postma and Boezen 2004; Tetley 1993). Several lines of evidence are suggestive for the validity of the hypothesis: 1. instillation of elastase can induce emphysema in the lungs of animals (Gross et al 1965; Janoff et al 1977; Snider et al 1984); 2. destruction of elastins by elastase and the loss of elastic recoil (Campbell et al 1987; Shapiro et al 2003); and 3. genetic deficiency of $\alpha 1$-proteinase inhibitor increases the susceptibility to the development of emphysema (Laurell and Eriksson 1963; Stoller and Aboussouan 2005). Together with the fact that proteolytic enzymes produce many of the clinical and pathological features of COPD, these observations firmly establish the concept that enzyme activity and tissue damage in emphysema are the result of excess release of proteinases, or a reduction in the levels of inhibitors required to control them.

\section{SECRETORY LEUKOCYTE PROTEINASE INHIBITOR}

Since most of the other anti-proteases, such as SLPI and elafin, are considerably smaller molecules than A1AT, these molecules are thought to be active in areas such as intercellular spaces that are not accessible to the larger A1AT molecule (Ayad et al 2003; Vogelmeier et al 1991). However, even very small molecular weight inhibitors are no better than A1AT in studies looking at the process of quantum proteolysis (Campbell et al 1999). SLPI has a major benefit that relates to the fact that it can inhibit elastase bound to connective tissue substrate, whereas A1AT is not very good at this. This gives an impression that SLPI actually gets under the cell, whereas it is a very different mechanism. Although SLPI, like A1AT, is inactivated by cigarette smoke-induced oxidation, oxidized SLPI maintains its anti-proteinase activity particularly at high concentrations (Boudier and Bieth 1994). It has been proposed that SLPI is important for protecting the respiratory epithelium because of its location in the bronchi (Ohlsson and Tegner 1976; Tegner 1978). In contrast to A1AT, SLPI blocks elastase in the alveolar walls (Bruch and Bieth 1986). Ayad et al (2003) demonstrated higher concentrations of SLPI in serum and BAL fluid in A1AT deficient individuals as compared to normal PiM subjects. They speculated that there may be some genetic, or other, compensatory processes leading to an increase in SLPI in A1AT deficient individuals. SLPI can protect the lung against the development of emphysema in A1AT deficient subjects and cigarette smokers have lower SLPI concentrations than never-smokers, presumably due to irreversible bronchial epithelial damage. The relationship may be false, because A1AT deficient subjects may have more mucus hypersecretion, which could raise the SLPI level above that of individuals who have no mucus hypersecretion. However, in studies reported by Hill et al (1999, 2000), having appropriate controls between deficient and non-deficient subjects, it was clear that SLPI was actually lower and this is consistent with an effect of proteolytic enzymes, which cause a reduction in SLPI secretion from airway cells. It is also consistent with the reduction in SLPI that occurs during acute exacerbations when elastase activity rises. In contrast, Hollander et al (2007) could not demonstrate increased levels of SLPI and $\alpha_{1}-1$-antichymotrypsin in plasma of A1AT deficient individuals. Their argument is that increased protease inhibitor levels in plasma occur at young age, and decrease to normal levels with increasing age. This is supported by some reports (Ganrot 1968; Tunstall et al 1975). They also question if plasma is the relevant biological fluid to measure SLPI, since SLPI is produced locally in the airways and is regulated by various pro-inflammatory stimuli. Other serine protease inhibitors, such as $\alpha-1$ antichymotrypsin, $\alpha$-2-macroglobulin, anti-thrombin, and anti-plasmin play also important roles in controlling serine protease activity. While these inhibitors are produced mainly by the liver and reach the other tissues by passive diffusion (Kalsheker et al 2002; Morrison et al 1987; Vignola et al 1998), SLPI and elafin are produced locally by airway epithelial cells (Sallenave et al 1994, 1997). Thus, it cannot be excluded that under inflammatory conditions the compensatory increase in SLPI and/or other protease inhibitors may reduce the severity of A1AT deficiency. SLPI is considered equipotent to A1AT as an airway anti-proteinase. DNA derived from individuals with a broad range of A1AT mutations, many of which occur in high frequency, and analyzed for SLPI mutations has been found to have no polymorphisms in the major SLPI coding exons (Abe et al 1991). In addition, no polymorphisms were detected in individuals who had obstructive lung disease at an early age, but did not have A1AT deficiency or cystic fibrosis, i.e., hypothetically those who had an increased chance of having an abnormal SLPI gene that might be responsible for their disease (Abe et al 1991; Chang et al 2006). These data suggest that structural mutations in SLPI may not be involved in the pathogenesis of COPD (Ning et al 2004). 


\section{Metalloproteases ANd Elastase}

One of the most prominent families of proteases cleaved by elastase is the group of matrix metalloproteases. Serine proteases such as elastase, cathepsin G, and proteinase- 3 have been shown to activate MMP-2, and this activation could be blocked by $\alpha_{1}$-antitrypsin, but not by an MMP-inhibitor (Shamamian et al 2001). Geraghty et al (2007) have demonstrated that elastase could induce cathepsin G and MMP-2 expression and activity in macrophages. Their study provides data that elastase presides over a novel hierarchy in protease regulation, causing tissue destruction in diseases associated with a high burden of elastase. The up-regulation and release of cathepsin B by elastase is an interesting observation. Zheng et al (2000) were the first to demonstrate that cathepsins are released in response to cigarette smoke. Mediators that generate Th2-type tissue inflammatory responses are also able to activate proteolytic pathways. By using an overexpressing transgenic modelling system to target IL-13 to the murine lung, they were able to induce a phenotype that is equal to human COPD with prominent emphysema, enlarged lungs, enhanced pulmonary compliance, mucus metaplasia, and a mixed tissue inflammation. The cathepsins, but also metalloproteinases were induced by IL-13 and it has been suggested that IL-13 is an important regulator of the protease/antiprotease balance contributing to the pathogenesis of COPD. Earlier it was demonstrated that MMP-12 is essential for cigarette smoke-induced inflammation and emphysema in the murine lung (Hautamaki et al 1997) and that MMP-12 expression is enhanced in alveolar macrophages from smokers and patients with emphysema (Shapiro 2000).

Zheng et al (2000) have also studied the effects of metalloproteinase and cathepsin proteinase inhibitors on the outcome of IL-13 induced emphysema. These experiments show that these antagonists partially abrogated the IL-13-induced emphysema and that they were more effective at reducing lung volume and alveolar destruction when used in combination. Levels of a variety of important antiproteases in the lungs of IL-13 overexpressing animals, such as TIMP-2, TIMP3, TIMP-4, SLPI, and cystatin C, were not changed. An increased expression of TIMP-1 was noted as being not of sufficient magnitude to inhibit the induced emphysema. However, the expression of A1AT was decreased. The biological significance of the latter observations is questionable because the level of A1AT produced by the liver is exceeding that of lung-derived A1AT. When cathepsin B is converted into an active form by elastase (Burnett et al 1995), it is able to inactivate important respiratory tract innate immune proteins such as SLPI, human $\beta$-defensins 2 and 3, and lactoferrin (Geraghty et al 2007; Rogan et al 2004; Taggart et al 2003). In that way, elastase-induced cathepsin B release may not only lead to degradation of the extracellular matrix, it will also have an impact on important antimicrobial peptides and proteins.

Although tobacco smoking is an important inducer of COPD, it is not the sole course, because other causes are abnormal recruitment and activation of inflammatory cells and excess levels of free radicals.
Nevertheless, smoking-induced emphysema both in humans and in animal models results from enzymes derived from alveolar macrophages, more precisely the metalloproteinases (MacNee 2007). Mice deficient in macrophage elastase (MMP-12) and rats depleted of macrophages did not develop emphysema after longterm smoke exposure (Hautamaki et al 1997; Ofulue and Ko 1999). However, neutrophils also secrete cathepsin and MMP-8 and MMP-9 beside elastase. Several studies still confirm the importance of the neutrophil in emphysema (Churg et al 2003a; Shapiro et al 2003). There is a considerable interaction between the metalloproteinases, with MMP-1 activating MMP-2, MMP-2 activating MMP-1 and MMP-12, and MMP-13 activating MMP-9 (McCawley and Matrisian 2001; Wright and Churg 2007). Which metalloproteinases are actually important in emphysema is a controversial issue. Increased levels of MMP-1, MMP-9, and MMP-12 have been found in the lungs of emphysema patients (Demedts et al 2006; Finlay et al 1997; Imai et al 2001; Molet et al 2005; Ohnishi et al 1998; Russell et al 2002). Thus, collagenases, gelatinases, and elastases appear to be important in emphysema, but the different metalloproteinases may play different roles in animals compared to humans. TNF- $\alpha$ serves as a central mediator. It activates a proteinase cascade and the mediator itself is activated by proteinases. Macrophage-derived MMP-12 is able to liberate TNF$\alpha$ from the surface of the macrophage, resulting in infiltration of neutrophils by activation of endothelial cells. The migrated neutrophils, in turn, release elastase upon TNF- $\alpha$ stimulation. Moreover, MMP-12 and the neutrophil-derived elastase potentiate the action of each other by inactivating A1AT and TIMP-1, respectively (Shapiro et al 2003). In a recent study, it has been shown that the number of MMP-12 positive macrophages in lavage fluid of smokers with COPD was higher compared with ex-smokers with COPD, healthy smokers, and healthy never-smokers (Babusyte et al 2007). A similar result was observed for MMP-12 positive macrophages in induced sputum from these patients. Although the number of macrophages in induced sputum was not significantly higher in smokers with COPD compared with the ex-smokers with COPD, several studies show that MMP-12 may indeed play a role in COPD in humans. The expression of MMP-12 in healthy smokers is increased compared with non-smokers, supporting the suggestion that smoking may increase the expression of this enzyme (Babusyte et al 2007; Demedts et al 2006; Molet et al 2005). The contribution of MMP-12 to smoke-induced emphysema is probably enhanced by indirect effects, such as inactivation of A1AT (Gronski, Jr. et al 1997), and MMP-12 mediated recruitment of neutrophils to the lung (Churg et al 2003a). Otherwise, MMP-12 may accumulate and would not rapidly decreases or become inactivated after smoking cessation, exaggerating a persistent inflammation. In a very recent paper, Lowrey et al (2008) have described that MMP-9 protein, but not metalloproteinase activity, was higher in sputum of COPD patients compared with smoking controls. They suggest that MMP-9 levels may not reflect the overall metalloproteinase activity in the airways of COPD patients, reflecting a 
complex relationship between MMP-9 levels and activity.

Another striking finding is that A1AT administration to a model of cigarette smoke exposed mice is able to suppress smoking-induced increases in serum $\mathrm{TNF}-\alpha$, and a decreased inflammatory cell influx into the lung (Churg et al 2003b). Recent work has shown that A1AT inhibits lipopolysaccharide-mediated increases in TNF- $\alpha$ and IL-1 $\beta$ release from human blood monocytes (Janciauskiene et al 2004, 2007; Nita et al 2005). Similarly, administration of A1AT to patients with deficiency of the anti-proteinase decreased sputum elastase activity, and sputum levels of leukotrienes B4 (Stockley et al 2002). In addition, A1AT can inhibit both thrombin and plasmin, preventing release of MMP-12 and TNF- $\alpha$ (Churg et al 2007). Important in this case is also the enhancing effect of A1AT on LPS-stimulated IL-10 generation, because it influences a specific mechanism for the effects of A1AT rather than a general depressive effect of A1AT on cell function (Janciauskiene et al 2004). Thus, we might say that A1AT not only is a protease inhibitor, it also exhibits anti-inflammatory properties.

\section{IMPLICATIONS FOR TREATMENT}

Medical treatment of elastase-induced emphysema is similar to the treatment of general COPD and should be tailored to each individual patient. The targets of treatment are the prevention of accelerated decline of pulmonary function, reduction of lung infections, and improvements in exercise capacity. However, none of the existing pharmaceutical treatments for COPD has been shown to modify the long-term decline in lung function. Therefore, pharmacotherapy is used to decrease symptoms and/or complications (Chrystyn et al 1988; Gross et al 1989; Higgins et al 1991; Vathenen et al 1988). Pharmaceutical treatment consists of application of long-acting $\beta_{2}$-agonists, formoterol or salmeterol. The combination of $\beta_{2}$-agonists with long-acting anticholinergic tiotropium or theophylline may provide additional improvement in lung function and health status (Guyatt et al 1987; The COMBIVENT Inhalation Solution Study Group 1997). Short-acting $\beta_{2}$-agonists may only provide relief in acute situations. The mucolytic and antioxidant $\mathrm{N}$-acetylcysteine has proven itself as a mucolytic, but its anti-inflammatory properties are rather limited (Decramer et al 2005; Petty 1990; van Overveld et al 2005). The benefit of inhaled corticosteroids is widely debated. Oxygen therapy enables many patients with severe COPD to lead a more normal life and increase survival (Nocturnal Oxygen Therapy Trial Group 1980; Report of the Medical Research Council Working Party 1981). Physical exercise will improve breathing ability by relieving dyspnea and fatigue (Berry et al 1999). Surgical approaches to improving dyspnea by removing areas of major lung damage from emphysema are only effective in a very small and carefully selected part of the patient population (Mehran and Deslauriers 1995; Naunheim et al 2006). Finally, substitution therapy with human A1AT in non-smoking patients with low A1AT serum levels $(<0.8 \mathrm{~g} / \mathrm{l})$ is performed for about ten years in a small number of countries. In addition to the high cost of this therapy, the evidence for its efficacy is limited (Köhnlein and Welte 2008). The development of elastase inhibitors has significantly increased our knowledge. In the last 15 years, elastase inhibitors have been used in many animal studies. Among the inhibitors are chloromethylketone, ICI200,355, L-658,758, ONO-5046, and SC-39026. However, SLPI is easy to produce synthetically. In addition, when delivered by aerosol SLPI is retained in the epithelial lining fluid of the lungs with a sufficient long half-life of 12 hours. A third advantage is the insensitivity to MMP-8, a factor generally abundant at sites with high elastase concentrations (Fitch et al 2006). Delivery of exogenous proteinase inhibitors might thus have many advantages in the treatment of COPD, and SLPI seems to be a promising candidate.

\section{CONCLUSIONS}

In general, we might say that the major proteinases involved in the pathogenesis of COPD include those produced by neutrophils (elastase, cathepsin $G$ and proteinase-3) and macrophages (cathepsins), and various metalloproteinases. The major anti-proteinases involved in the pathogenesis of COPD include alpha-1antitrypsin, secretory leukocyte proteinase inhibitor, and the tissue inhibitors of MMPs. As soon as the fragile equilibrium is disturbed by external or internal factors, the individual is prone to the development of chronic and destructive lung disease, leading to disability, and ultimately death.

Conflicts of interest: The authors declare no conflict of interest in relation to this article.

\section{REFERENCES}

Abe T, Kobayashi N, Yoshimura K, Trapnell BC, Kim H, Hubbard RC, Brewer MT, Thompson RC, Crystal RG. Expression of the secretory leukoprotease inhibitor gene in epithelial cells. J Clin Invest 1991; 87: 2207-15.

Ayad MS, Knight KR, Burdon JGW, Brenton S. Secretory leukocyte proteinase inhibitor, alpha-1-antitrypsin deficiency and emphysema: Preliminary study, speculation and an hypothesis. Respirology 2003; 8: 175-80.

Babusyte A, Stravinskaite K, Jeroch J, Lötvall J, Sakalauskas R, Sitkauskiene B. Patterns of airway inflammation and MMP-12 expression in smokers and ex-smokers with COPD. Respir Res 2007; 8: 81.

Barrett AJ. Leukocyte elastase. Methods Enzymol 1981; 80: 581-8.

Belvisi MG, Bottomley KM. The role of matrix metalloproteinases (MMPs) in the pathophysiology of chronic obstructive pulmonary disease (COPD): A therapeutic role for inhibitors of MMPs? Inflamm Res 2003; 52: 95-100.

Berry MJ, Rejeski WJ, Adair NE, Zaccaro D. Exercise rehabilitation and chronic obstructive pulmonary disease stage. Am J Respir Crit Care Med 1999; 160: 1248-53.

Boudier C, Bieth JG. Oxidized mucus proteinase inhibitor: A fairly potent neutrophil elastase inhibitor. Biochem J 1994; 303: 61-8.

Brantly M, Nukiwa T, Crystal RG. Molecular basis of alpha1-antitrypsin deficiency. Am J Med 1998; 84: 13-31.

Bruch M, Bieth JG. Influence of elastin on the inhibition of leucocyte elastase by alpha 1 -proteinase inhibitor and bronchial inhibitor. Potent inhibition of elastin-bound elastase by bronchial inhibitor. Biochem J 1986; 238: 269-73. 
Burdon JGW, Knight KR, Brenton S, Cook L. Antiproteinase deficiency, emphysema and replacement therapy. Aust NZ J Med 1996; 26: 769-71.

Burnett D, Abrahamson M, Devalia JL, Sapsford RJ, Davies RJ, Buttle DJ. Synthesis and secretion of procathepsin B and cystatin $C$ by human bronchial epithelial cells in vitro: modulation of cathepsin B activity by neutrophil elastase. Arch Biochem Biophys 1995; 317: 305-10.

Campbell EJ, Campbell MA, Boukedes SS, Owen CA. Quantum proteolysis by neutrophils: Implications for pulmonary emphysema in alpha 1-antitrypsin deficiency. J Clin Invest 1999; 104: 337-44.

Campbell EJ, Senior RM, Welgus HG. Extracellular matrix injury during lung inflammation. Chest 1987; 92: 161-7.

Cao Z, Henzel WJ, Gao X. IRAK: A kinase associated with the interleukin-1 receptor. Science 1996; 271: 1128-31.

Chang YP, Mahadeva R, Chang WS, Shukla A, Dafforn TR, Chu YH. Identification of a 4-mer peptide inhibitor that effectively blocks the polymerization of pathogenic $\mathrm{Z}$ alpha1-antitrypsin. Am J Respir Cell Mol Biol 2006; 35: 540-8.

Chapman KR, Mannino DM, Soriano JB, Vermeire PA, Buist AS, Thun MJ, Connell C, Jemal A, Lee TA, Miravitlles M, Aldington S, Beasley R. Epidemiology and costs of chronic obstructive pulmonary disease. Eur Respir J 2006; 27: 188-207.

Chrystyn H, Mulley BA, Peake MD. Dose response relation to oral theophylline in severe chronic obstructive airways disease. Br Med J 1988; 297: 1506-10.

Chung KF. Cytokines in chronic obstructive pulmonary disease. Eur Respir J 2001; 34: 50s-9s.

Churg A, Dai J, Tai H, Xie C, Wright JL. Tumor necrosis factor-alpha is central to acute cigarette smoke induced inflammation and connective tissue breakdown. Am J Respir Crit Care Med 2002; 166: 849-54.

Churg A, Wang RD, Tai H, Wang X, Xie C, Dai J, Shapiro SD, Wright JL. Macrophage metalloelastase mediates acute cigarette smoke-induced inflammation via tumor necrosis factor-alpha release. Am J Respir Crit Care Med 2003a; 167: 1083-9.

Churg A, Wang RD, Xie C, Wright JL. Alpha-1-antitrypsin ameliorates cigarette smoke-induced emphysema in the mouse. Am J Respir Crit Care Med 2003b; 168: 199-207.

Churg A, Wang RD, Tai H, Wang X, Xie C, Wright JL. Tumor necrosis factor-alpha drives $70 \%$ of cigarette smoke-induced emphysema in the mouse. Am J Respir Crit Care Med 2004; 170: 492-8.

Churg A, Wang X, Wang RD, Meixner SC, Pryzdial EL, Wright JL. Alpha 1-Antitrypsin suppresses TNF-alpha and MMP-12 production by cigarette smoke-stimulated macrophages. Am J Respir Cell Mol Biol 2007; 37: 144-51.

Crystal RG. The alpha-1-antitrypsin gene and its deficiency states. Trends Genet 1989; 5: 411-7.

Davies M, Barrett AJ, Travis J, Sanders E, Coles GA. The degradation of human glomerular basement membrane with purified lysosomal proteinases: Evidence for the pathogenic role of the polymorphonuclear leucocyte in glomerulonephritis. Clin Sci Mol Med 1978; 54: 233-40.

De Backer WA, Amsel B, Jorens PG, Bossaert L, Hiemstra PS, van Noort P, van Overveld FJ. N-Acetylcysteine pretreatment of cardiac surgery patients influences plasma neutrophil elastase and neutrophil influx in bronchoalveolar lavage fluid. Intensive Care Med 1996; 22: 900-8.

de Serres FJ. Worldwide racial and ethnic distribution of alpha1-antitrypsin deficiency: summary of an analysis of published genetic epidemiologic surveys. Chest 2002; 122 : 1818-29.

Decramer M, Rutten-van Mölken M, Dekhuijzen PN, Troosters T, van Herwaarden C, Pellegrino R, van Schayck CP, Olivieri D, Del Donno M, De Backer WA, Lankhorst I, Ardia A. Effects of N-acetylcysteine on outcomes in chron- ic obstructive pulmonary disease (Bronchitis Randomized on NAC Cost-Utility Study, BRONCUS): A randomised placebo-controlled trial. Lancet 2005; 365: 1552-60.

Demedts IK, Morel-Montero A, Lebecque S, Pacheco Y, Cataldo D, Joos GF, Pauwels RA, Brusselle GG. Elevated MMP-12 protein levels in induced sputum from patients with COPD. Thorax 2006; 61: 196-201.

Eriksson S. Studies in alpha 1-antitrypsin deficiency. ActaMed Scand 1965; 432: 1-85.

Fagerholm MK, Laurell CB. The polymorphism of "prealbumins" and alpha-1-antitrypsin in human sera. Clin Chim Acta 1967; 16: 199-203.

Finkelstein R, Fraser RS, Ghezzo H, Cosio MG. Alveolar inflammation and its relation to emphysema in smokers. Am J Respir Crit Care Med 1995; 152: 1666-72.

Finlay GA, O'Driscoll LR, Russell KJ, D’Arcy EM, Masterson JB, Fitzgerald MX, O'Connor CM. Matrix metalloproteinase expression and production by alveolar macrophages in emphysema. Am J Respir Crit Care Med 1997; 156: 240-7.

Fitch PM, Roghanian A, Howie SEM, Sallenave JM. Human neutrophil elastase inhibitors in innate and adaptive immunity. Biochem Soc Trans 2006; 34: 279-82.

Gadek JE, Fells GA, Wright DG, Crystal RG. Human neutrophil elastase functions as a type III collagen "collagenase". Biochem Biophys Res Commun 1980; 95: 1815-22.

Ganrot PO. Variation of the alpha-2-macroglobulin homologue with age in some mammals. Scand J Clin Lab Invest 1968; 21: 177-81.

Geraghty P, Rogan MP, Greene CM, Boxio RM, Poiriert T, O’Mahony M, Belaaouaj A, O’Neill SJ, Taggart CC, McElvaney NG. Neutrophil elastase up-regulates cathepsin $\mathrm{B}$ and matrix metalloprotease- 2 expression. J Immunol 2007; 178: 5871-8.

Gettins PG. Serpin structure, mechanism, and function. Chem Rev 2002; 102: 4751-804.

Gronski TJ, Jr., Martin RL, Kobayashi DK, Walsh BC, Holman MC, Huber M, Van Wart HE, Shapiro SD. Hydrolysis of a broad spectrum of extracellular matrix proteins by human macrophage elastase. J Biol Chem 1997; 272: 12189-94.

Gross NJ, Petty TL, Friedman M, Skorodin MS, Silvers GW, Donohue JF. Dose response to ipratropium as a nebulized solution in patients with chronic obstructive pulmonary disease. A three-center study. Am Rev Respir Dis 1989; 140: 1188-91.

Gross P, Pfitzer EA, Tolker E, Babyak MA, Kaschak M. Experimental emphysema: Its production with papain in normal and silicotic rats. Arch Environ Health 1965; 11: 50-8.

Guyatt GH, Berman LB, Townsend M, Pugsley SO, Chambers LW. A measure of quality of life for clinical trials in chronic lung disease. Thorax 1987; 42: 773-8.

Halbert RJ, Natoli JL, Gano A, Badamgarav E, Buist AS, Mannino DM. Global burden of COPD: Systematic review and meta-analysis. Eur Respir J 2006; 28: 523-32.

Hautamaki RD, Kobayashi DK, Senior RM, Shapiro SD. Requirement for macrophage elastase for cigarette smokeinduced emphysema in mice. Science 1997; 277: 2002-4.

Higgins BG, Powell RM, Cooper S, Tattersfield AE. Effect of salbutamol and ipratropium bromide on airway calibre and bronchial reactivity in asthma and chronic bronchitis. Eur Respir J 1991; 4: 415-20.

Hill AT, Bayley DL, Campbell EJ, Hill SL, Stockley RA. Airways inflammation in chronic bronchitis: The effects of smoking and alpha-1-antitrypsin deficiency. Eur Respir J 2000; 15: 886-90.

Hill AT, Campbell EJ, Bayley DL, Hill SL, Stockley RA. Evidence for excessive bronchial inflammation during an acute exacerbation of chronic obstructive pulmonary disease in patients with alpha-1-antitrypsin deficiency (PiZ). Am J Respir Crit Care Med 1999; 160: 1968-75. 
Hoidal JR. Genetics of COPD: Present and future. Eur Respir J 2001; 18: 741-3.

Hollander C, Westin U, Wallmark A, Piitulainen E, Sveger T, Janciauskiene SM. Plasma levels of alpha-1-antichymotrypsin and secretory leukocyte proteinase inhibitor in healthy and chronic obstructive pulmonary disease (COPD) subjects with and without severe alpha-1-antitrypsin deficiency. BMC Pulm Med 2007; 7: 1.

Imai K, Dalal SS, Chen ES, Downey R, Schulman LL, Ginsburg M, D'Armiento J. Human collagenase (matrix metalloproteinase-1) expression in the lungs of patients with emphysema. Am J Respir Crit Care Med 2001; 163: 78691.

Janciauskiene SM, Larsson S, Larsson P, Virtala R, Jansson L, Stevens T. Inhibition of lipopolysaccharide-mediated human monocyte activation, in vitro, by alpha-1-antitrypsin. Biochem Biophys Res Commun 2004; 321: 592-600.

Janciauskiene SM, Nita IM, Stevens T. Alpha-1-antitrypsin, old $\operatorname{dog}$, new tricks. Alpha-1-antitrypsin exerts in vitro anti-inflammatory activity in human monocytes by elevating cAMP. J Biol Chem 2007; 282: 8573-82.

Janoff A, Sloan B, Weinbaum G, Damiano V, Sandhaus RA, Elias J, Kimbel P. Experimental emphysema induced with purified human neutrophil elastase: Tissue localization of the instilled protease. Am Rev Respir Dis 1977; 115: 46178.

Jeffery PK. Remodeling in asthma and chronic obstructive lung disease. Am J Respir Crit Care Med 2001; 164: 28S38.

Kalsheker N, Morley S, Morgan K. Gene regulation of the serine proteinase inhibitors alpha-1-antitrypsin and alpha1-antichymotrypsin. Biochem Soc Trans 2002; 30: 93-8.

Köhnlein T, Welte T. Alpha-1-antitrypsin deficiency: Pathogenesis, clinical presentation, diagnosis, and treatment. Am J Med 2008; 121: 3-9.

Kueppers F, Miller RD, Gordon H, Hepper NG, Offord KP. Familial prevalence of chronic obstructive pulmonary disease in a matched pair study. Am J Med 1977a; 63: 33642.

Kueppers F, Utz G, Simon B. Alpha1-antitrypsin deficiency with M-like phenotype. J Med Genet 1977b; 14: 183-6.

Kusano K, Miyaura C, Inada M, Tamura T, Ito A, Nagase H, Kamoi K, Suda T. Regulation of matrix metalloproteinases (MMP-2, -3, -9, and -13) by interleukin-1 and interleukin-6 in mouse calvaria: Association of MMP induction with bone resorption. Endocrinology 1998; 139: 1338-45.

Laurell CB, Eriksson S. The electrophoretic alpha-1-globulin pattern of serum alpha-1-antitrypsin deficiency. Scand J Clin Lab Invest 1963; 15: 132-40.

Lowrey GE, Henderson N, Blakey JD, Corne JM, Johnson SR. MMP-9 protein level does not reflect overall MMP activity in the airways of patients with COPD. Respir Med 2008; 102: 845-51.

Luisetti M, Seersholm N. Alpha-1-antitrypsin deficiency. I: Epidemiology of alpha-1-antitrypsin deficiency. Thorax 2004; 59: 164-9.

MacNee W. Pathogenesis of chronic obstructive pulmonary disease. Clin Chest Med 2007; 28: 479-513.

McCawley LJ, Matrisian LM. Matrix metalloproteinases: They're not just for matrix anymore. Curr Opin Cell Biol 2001; 13: 534-40.

McDonald JA, Kelley DG. Degradation of fibronectin by human leukocyte elastase. Release of biologically active fragments. J Biol Chem 1980; 255: 8848-58.

Mehran RJ, Deslauriers J. Indications for surgery and patient work-up for bullectomy. Chest Surg Clin N Am 1995; 5: 717-34.

Molet S, Belleguic C, Lena H, Germain N, Bertrand CP, Shapiro SD, Planquois JM, Delaval P, Lagente V. Increase in macrophage elastase (MMP-12) in lungs from patients with chronic obstructive pulmonary disease. Inflamm Res 2005; 54: 31-6.

Morrison HM, Kramps JA, Burnett D, Stockley RA. Lung lavage fluid from patients with alpha-1-proteinase inhibitor deficiency or chronic obstructive bronchitis: Antielastase function and cell profile. Clin Sci 1987; 72: 37381.

Nadel JA. Role of mast cell and neutrophil proteases in airway secretion. Am Rev Respir Dis 1991; 144: S48-S51.

Nagasawa H, Sasaki H, Uto Y, Kubo S, Hori H. Association of the macrophage activating factor (MAF) precursor activity with polymorphism in vitamin D-binding protein. Anticancer Res 2004; 24: 3361-6.

Naunheim KS, Wood DE, Mohsenifar Z, Sternberg AL, Criner GJ, DeCamp MM, Deschamps CC, Martinez FJ, Sciurba FC, Tonascia J, Fishman AP; National Emphysema Treatment Trial Research Group. Long-term followup of patients receiving lung-volume-reduction surgery versus medical therapy for severe emphysema by the $\mathrm{Na}$ tional Emphysema Treatment Trial Research Group. Ann Thorac Surg 2006; 82: 431-43.

Ning W, Li CJ, Kaminski N, Feghali-Bostwick CA, Alber SM, Di YP, Otterbein SL, Song R, Hayashi S, Zhou Z, Pinsky DJ, Watkins SC, Pilewski JM, Sciurba FC, Peters DG, Hogg JC, Choi AM. Comprehensive gene expression profiles reveal pathways related to the pathogenesis of chronic obstructive pulmonary disease. Proc Natl Acad Sci USA 2004; 41: 14895-900.

Nita I, Hollander C, Westin U, Janciauskiene SM. Prolastin, a pharmaceutical preparation of purified human alpha-1antitrypsin, blocks endotoxin-mediated cytokine release. Respir Res 2005; 6: 12.

Nocturnal Oxygen Therapy Trial Group. Continuous or nocturnal oxygen therapy in hypoxemic chronic obstructive lung disease: A clinical trial. Ann Intern Med 1980; 93: 391-8.

Ofulue AF, Ko M. Effects of depletion of neutrophils or macrophages on development of cigarette smoke-induced emphysema. Am J Physiol 1999; 277: L97-L105.

Ohlsson K, Tegner H. Inhibition of elastase from granulocytes by the low molecular weight bronchial protease inhibitor. Scand J Clin Lab Invest 1976; 36: 437-45.

Ohnishi K, Takagi M, Kurokawa Y, Satomi S, Konttinen YT. Matrix metalloproteinase-mediated extracellular matrix protein degradation in human pulmonary emphysema. Lab Invest 1998; 78: 1077-87.

Ongagna JC, Pinget M, Belcourt A. Vitamin D-binding protein gene polymorphism association with IA-2 autoantibodies in type 1 diabetes. Clin Biochem 2005; 38: 415-9.

Pauwels RA, Buist AS, Calverley PMA, Jenkins CR, Hurd SS, GOLD Scientific Committee. Global strategy for the diagnosis, management, and prevention of chronic obstructive pulmonary disease: NHLBI Global Initiative for Chronic Obstructive Lung Disease (GOLD). Workshop Summary. Am J Respir Crit Care Med 2001; 163: 1256-76.

Petty TL. The National Mucolytic Study. Results of a randomized, double-blind, placebo-controlled study of iodinated glycerol in chronic obstructive bronchitis. Chest 1990; 97: 75-83.

Poller W, Barth J, Voss B. Detection of an alteration of the alpha-2-macroglobulin gene in a patient with chronic lung disease and serum alpha-2-macroglobulin deficiency. Hum Genet 1989; 83: 93-6.

Postma DS, Boezen HM. Rationale for the Dutch hypothesis. Allergy and airway hyperresponsiveness as genetic factors and their interaction with environment in the development of asthma and COPD. Chest 2004; 126: 96S-104S.

Report of the Medical Research Council Working Party. Long term domiciliary oxygen therapy in chronic hypoxic cor pulmonale complicating chronic bronchitis and emphysema. Lancet 1981; 1: 681-6. 
Rogan MP, Taggart CC, Greene CM, Murphy PG, O’Neill SJ, McElvaney NG. Loss of microbicidal activity and increased formation of biofilm due to decreased lactoferrin activity in patients with cystic fibrosis. J Infect Dis 2004; 190: 1245-53.

Roughley PJ, Barrett AJ. The degradation of cartilage proteoglycans by tissue proteinases. Proteoglycan structure and its susceptibility to proteolysis. Biochem J 1977; 167: 62937.

Russell RE, Culpitt SV, de Matos C, Donnelly L, Smith M, Wiggins J, Barnes PJ. Release and activity of matrix metalloproteinase-9 and tissue inhibitor of metalloproteinase- 1 by alveolar macrophages from patients with chronic obstructive pulmonary disease. Am J Respir Cell Mol Biol 2002; 26: 602-9.

Saetta M, Di Stefano A, Maestrelli P, Turato G, Mapp CE, Pieno M, Zanguochi G, Del Prete G, Fabbri LM. Airway eosinophilia and expression of interleukin-5 protein in asthma and in exacerbation of chronic bronchitis. Clin Exp Allergy 1996; 26: 766-74.

Saetta M, Di Stefano A, Maestrelli P, Turato G, Ruggieri MP, Roggeri A, Calcagni P, Mapp CE, Ciaccia A, Fabbri LM. Airway eosinophilia in chronic bronchitis during exacerbations. Am J Respir Crit Care Med 1994; 150: 1646-52.

Saetta M, Di Stefano A, Turato G, Facchini FM, Corbino L, Mapp CE, Maestrelli P, Ciaccia A, Fabbri LM. CD8+ Tlymphocytes in peripheral airways of smokers with chronic obstructive pulmonary disease. Am J Respir Crit Care Med 1998; 157: 822-6.

Saetta M, Turato G, Maestrelli P, Mapp CE, Fabbri LM. Cellular and structural bases of Chronic Obstructive Pulmonary Disease. Am J Respir Crit Care Med 2001; 163: 1304-9.

Sallenave JM, Shulmann J, Crossley J, Jordana M, Gauldie J. Regulation of secretory leukocyte proteinase inhibitor (SLPI) and elastase-specific inhibitor (ESI/elafin) in human airway epithelial cells by cytokines and neutrophilic enzymes. Am J Respir Cell Mol Biol 1994; 11: 733-41.

Sallenave JM, Si Tahar M, Cox G, Chignard M, Gauldie J. Secretory leukocyte proteinase inhibitor is a major leukocyte elastase inhibitor in human neutrophils. J Leukoc Biol 1997; 61: 695-702.

Sampsonas F, Karkoulias K, Kaparianos A, Spiropoulos K. Genetics of chronic obstructive pulmonary disease, beyond alpha-1-antitrypsin deficiency. Curr Med Chem 2006; 13: 2857-73.

Sandford AJ, Joos L, Pare PD. Genetic risk factors for chronic obstructive pulmonary disease. Curr Opin Pulm Med 2002; 8: 87-94.

Sandford AJ, Silverman EK. Chronic obstructive pulmonary disease. I: Susceptibility factors for COPD the genotypeenvironment interaction. Thorax 2002; 57: 736-41.

Senior RM, Bielefeld DR, Starcher BC. Comparison of the elastolytic effects of human leukocyte elastase and porcine pancreatic elastase. Biochem Biophys Res Commun 1976; 72: 1327-34.

Shamamian P, Schwartz JD, Pocock BJ, Monea S, Whiting D, Marcus SG, Mignatti P. Activation of progelatinase A (MMP-2) by neutrophil elastase, cathepsin G, and proteinase-3: A role for inflammatory cells in tumor invasion and angiogenesis. J Cell Physiol 2001; 189: 197-206.

Shapiro SD. The macrophage in chronic obstructive pulmonary disease. Am J Respir Crit Care Med 1999; 160: S29-S32.

Shapiro SD. Animal models for chronic obstructive pulmonary disease. Age of klotho and marlboro mice. Am J Respir Cell Mol Biol 2000; 22: 4-7.

Shapiro SD, Goldstein NM, Houghton AM, Kobayashi DK, Kelley D, Belaaouaj A. Neutrophil elastase contributes to cigarette smoke-induced emphysema in mice. Am J Pathol 2003; 163: 2329-35.
Siafakas NM, Tzortzaki EG. Few smokers develop COPD. Why? Respir Med 2002; 96: 615-24.

Sinha S, Watorek W, Karr S, Giles J, Bode W, Travis J. Primary structure of human neutrophil elastase. Proc Natl Acad Sci USA 1987; 84: 2228-32.

Snider GL. Understanding inflammation in Chronic Obstructive Pulmonary Disease. Am J Respir Crit Care Med 2003; 167: 1045-6.

Snider GL, Lucey EC, Christensen TG, Stone PJ, Calore JD, Catanese A, Franzblau C. Emphysema and bronchial secretory cell metaplasia induced in hamsters by human neutrophil products. Am Rev Respir Dis 1984; 129: 15560.

Snider GL, Lucey EC, Stone PJ. Animal models of emphysema. Am Rev Respir Dis 1986; 133: 149-69.

Snider GL, Stone PJ, Lucey EC, Breuer R, Calore JD, Seshadri T, Catanese A, Maschler R, Schnebli HP. Eglin-c, a polypeptide derived from the medicinal leech, prevents human neutrophil elastase-induced emphysema and bronchial secretory cell metaplasia in the hamster. Am Rev Respir Dis 1985; 132: 1155-61.

Sommerhoff CP, Nadel JA, Basbaum CB, Caughey GH. Neutrophil elastase and cathepsin $G$ stimulate secretion from cultured bovine airway gland serous cells. J Clin Invest 1990; 85: 682-9.

Starkey PM, Barrett AJ, Burleigh MC. The degradation of articular collagen by neutrophil proteinases. Biochem Biophys Acta 1977; 483: 386-97.

Steinberg J, Fink G, Picone AL, Searles B, Schiller H, Lee HM, Nieman G. Evidence of increased matrix metalloproteinase-9 concentration in patients following cardiopulmonary bypass. J Extra Corpor Technol 2001; 33: 218-22.

Stewart RJ, Marsden PA. Biologic control of the tumor necrosis factor and interleukin-1 signaling cascade. Am J Kidney Dis 1995; 25: 954-66.

Stockley RA. Proteolytic enzymes, their inhibitors and lung diseases. Clin Sci 1983; 64: 119-26.

Stockley RA, Bayley DL, Unsal I, Dowson LJ. The effect of augmentation therapy on bronchial inflammation in alpha-1-antitrypsin deficiency. Am J Respir Crit Care Med 2002; 165: 1494-8.

Stoller JK, Aboussouan LS. Alpha-1-antitrypsin deficiency. Lancet 2005; 365: 2225-36.

Taggart CC, Greene CM, Smith SG, Levine RL, McCray PB Jr, O'Neill S, McElvaney NG. Inactivation of beta-defensins 2 and 3 by elastolytic cathepsins. J Immunol 2003; 171: 931-7.

Takahashi H, Nukiwa T, Basset P, Crystal RG. Myelomonocytic cell lineage expression of the neutrophil elastase gene. J Biol Chem 1988; 263: 2543-7.

Tegner H. Quantitation of human granulocyte protease inhibitors in non-purulent bronchial lavage fluids. Acta Otolaryngol 1978; 85: 282-9.

Tetley TD. Proteinase imbalance: Its role in lung disease. Thorax 1993; 48: 560-5.

The COMBIVENT Inhalation Solution Study Group. Routine nebulized ipratropium and albuterol together are better than either alone in COPD. Chest 1997; 112: 1514-21.

Tunstall AM, Merriman JM, Milne I, James K. Normal and pathological serum levels of alpha 2-macroglobulins in men and mice. J Clin Pathol 1975; 28: 133-9.

van Overveld FJ, Demkow UA, Gorecka D, De Backer WA, Zielinski J. New developments in the treatment of COPD: comparing the effects of inhaled corticosteroids and N-acetylcysteine. J Physiol Pharmacol 2005; 56: 13542.

Vathenen AS, Britton JR, Ebden P, Cookson JB, Wharrad HJ, Tattersfield AE. High-dose inhaled albuterol in severe chronic airflow limitation. Am Rev Respir Dis 1988; 138: $850-5$. 
Vignola AM, Bonanno A, Mirabella A, Riccobono L, Mirabella F, Profita M, Bellia V, Bousquet J, Bonsignore G. Increased levels of elastase and alpha-1-antitrypsin in sputum of asthmatic patients. Am J Respir Crit Care Med 1998; 157: 505-11.

Vogelmeier C, Hubbard RC, Fells GA, Schnebli HP, Thompson RC, Fritz H, Crystal RG. Anti-neutrophil elastase defense of the normal human respiratory epithelial surface provided by the secretory leukoprotease inhibitor. J Clin Invest 1991; 87: 482-8.

Williams SE, Brown TI, Roghanian A, Sallenave JM. SLPI and elafin: One glove, many fingers. Clin Sci 2006; 110: 21-35.

Witko-Sarsat V, Halbwachs-Mecarelli L, Schuster A, Nusbaum P, Ueki I, Canteloup S, Lenoir G, DescampsLatscha B, Nadel JA. Proteinase-3, a potent secretagogue in airways, is present in cystic fibrosis sputum. Am J Respir Cell Mol Biol 1999; 20: 729-36.

Wright JL, Churg A. Current concepts in mechanisms of emphysema. Toxicol Pathol 2007; 35: 111-5.

Yoshida T, Tuder RM. Pathobiology of cigarette smoke-induced chronic obstructive pulmonary disease. Physiol Rev 2007; 87: 1047-82.

Zhang J, Kew RR. Identification of a region in the vitamin D-binding protein that mediates its $\mathrm{C} 5 \mathrm{a}$ chemotactic cofactor function. J Biol Chem 2004; 279: 53282-7.
Zheng T, Zhu Z, Wang Z, Homer RJ, Ma B, Riese RJ Jr Chapman HA Jr, Shapiro SD, Elias JA. Inducible targeting of IL-13 to the adult lung causes matrix metalloproteinase- and cathepsin-dependent emphysema. J Clin Invest 2000; 106: 1081-93.

Address for correspondence:

Frans J. van Overveld

4Clinics

Drève Richelle 161, bât. G

B-1410 Waterloo

Belgium

Phone: +32-488-822-224

frans.vanoverveld@telenet.be

Urszula Demkow

Dept. Lab. Diagn. \& Clin. Immunol.

Warsaw Medical University

24, Marszalkowska St.

00-576 Warsaw

Poland

Phone: +48-50-1588782

urszula.demkow@litewska.edu.pl 